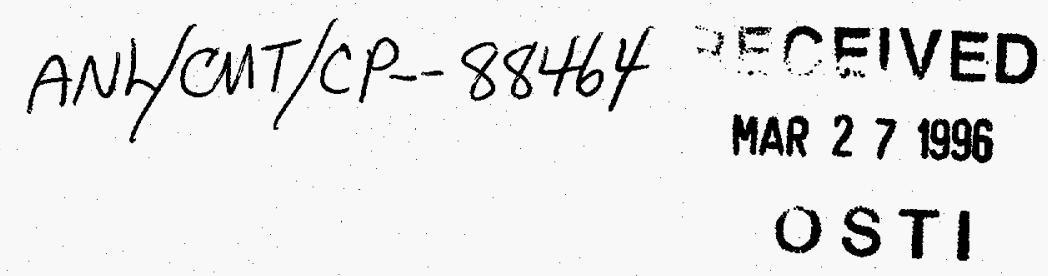

\title{
RADIONUCLIDE RELEASE FOR UNSATURATED SPENT FUEL TESTS - FIRST 1.6 YEARS
}

P. A. Finn, S. F. Wolf, and J. K. Bates

\author{
ARGONNE NATIONAL LABORATORY \\ Chemical Technology Division \\ 9700 South Cass Avenue \\ Argonne, IL 60439-4837
}

The submitfed manuscrpt has been authored
by a contractor of the U.S. Government under
contract No. W-31-108-ENG-38. Accordingly,
the U.S. Government retains a nonexclusive,
royalty-free license to publish or reproduce the
published form of this contribution, or allow
others to do so, for U.S. Government
purposes.

\author{
Submitted to \\ 1996 International High-Level Radioactive \\ Waste Management Conference \\ Las Vegas, Nevada \\ April 29-May 3, 1996
}

\begin{abstract}
*This task was performed under the guidance of the Yucca Mountain Site Characterization Project (YMP) and is part of activity D-20-43 in the YMP/Lawrence Livermore National Laboratory Spent Fuel Scientific Investigation Plan. This work was supported by the U.S. Department of Energy, under contract W-31-109-ENG-38.
\end{abstract}




\title{
RADIONUCLIDE RELEASE FOR UNSATURATED SPENT FUEL TESTS - FIRST 1.6 YEARS
}

\author{
P. A. Finn, S. F. Wolf, and J. K. Bates \\ Argonne National Laboratory \\ Chemical Technology Division \\ 9700 South Cass Avenue \\ Argonne, IL 60439-4837 \\ (708) 252-4511
}

\section{INTRODUCTION}

To provide input to evaluate the reaction of spent fuel for unsaturated conditions that may be expected in the Yucca Mountain candidate repository, we have ongoing tests at $90^{\circ} \mathrm{C}$ in which a simulated groundwater, EJ-13, is dripped at $0.75 \mathrm{~mL}$ at 3.5 day intervals on spent fuel samples. This paper examines the release behavior of ${ }^{238} \mathrm{U},{ }^{137} \mathrm{Cs}{ }^{90} \mathrm{Sr},{ }^{99} \mathrm{Tc}$, and ${ }^{129} \mathrm{I}$ to determine if any of them can represent matrix dissolution of spent fuel. The dissolution results reported from flow-through tests ${ }^{1,2}$ are used to provide a measure of the potential magnitude of matrix dissolution.

\section{DESCRIPTION}

Two pressurized-water-reactor fuels are used: ATM-103, fission gas release of $0.25 \%$, and ATM-106, fission gas release of $11.2 \%$. The experimental configuration and the composition of the leachant, EJ-13, is described elsewhere ${ }^{3}$. Cation content in aliquots of the leachate and the acid solutions used to strip the test vessel was determined using inductively coupled plasma-mass spectrometry. Details are given elsewhere ${ }^{4}$. The ${ }^{137} \mathrm{Cs}$ content was obtained from gamma spectrometry data.

\section{RESULTS AND DISCUSSION}

The location of ${ }^{137} \mathrm{Cs},{ }^{90} \mathrm{Sr},{ }^{129} \mathrm{I}$, and ${ }^{99} \mathrm{Tc}$ in a spent fuel pellet as reported by Gray et $\mathrm{al}^{1}$ and Wuertz and Wllinger ${ }^{5}$ is summarized in Table 1. Because the fuels used in these tests are the same as Gray's, we will use his ${ }^{99} \mathrm{Tc}$ values for comparison purposes. Wuertz's values for ${ }^{129} I$ may not be representative for our fuels since ATM-103 contains large amounts of $\mathrm{Xe}$ in particles along the grain boundaries, which suggests that ${ }^{129} \mathrm{I}$ is located there, and ATM-106 has a large fission gas release $(11.2 \%)$, which suggests a large ${ }^{129}$ I release to the gap.

The fractional releases and corresponding daily release rates for ${ }^{238} \mathrm{U},{ }^{137} \mathrm{Cs},{ }^{90} \mathrm{Sr},{ }^{229} \mathrm{I}$, and ${ }^{99} \mathrm{Tc}$ are listed in Table 2. The ${ }^{238} \mathrm{U}$ fraction is smaller than that of any of the other fractions. This finding can be correlated with the formation of large amounts of alteration products on the spent fuel, including a billietite-like phase containing barium, cesium and a very small amount of strontium. The ideal billietite formula is $\mathrm{Ba}\left(\mathrm{UO}_{2}\right)_{6} \mathrm{O}_{4}(\mathrm{OH})_{6} \cdot 8 \mathrm{H}_{2} \mathrm{O}$. The incorporation of cesium and strontium in alteration products reduces their measured release. For both ATM fuels, the ${ }^{90} \mathrm{Sr}$ release fractions were comparable to the ${ }^{137} \mathrm{Cs}$ fractions, ranging between $10^{-5}$ and $10^{-7} / \mathrm{d}$ in the ATM-106 test and falling from an initial value of $2 \times 10^{-4}$ to $4 \times 10^{-6} / \mathrm{d}$ in the ATM103 test.

We did not observe an initial large ${ }^{137} \mathrm{Cs}$ release, which has often been attributed to gap release. Rather, ${ }^{137} \mathrm{Cs}$ release from the ATM-103 fuel was relatively constant during the first 1.6 years of reaction while for the ATM-106 fuel, a delay was noted with significant release after four months of reaction. Since the ${ }^{137} \mathrm{Cs}$ cumulative released fraction in our tests is significantly smaller than the ${ }^{129} \mathrm{I}$ and the ${ }^{99} \mathrm{Tc}$ fractions, we suggest that cesium is being incorporated into alteration products, and the release of either ${ }^{129} \mathrm{I}$ or ${ }^{99} \mathrm{Tc}$ may better reflect the dissolution rate of the spent fuel matrix.

Although the ${ }^{129} \mathrm{I}$ release fractions for both fuels were orders of magnitude larger than those for ${ }^{238} \mathrm{U}$ and ${ }^{137} \mathrm{Cs}$, a decrease in ${ }^{129} \mathrm{I}$ release with 
time was noted for both fuels after nine months of reaction. Since the fission gas release for ATM-106 was $11.2 \%$, a large ${ }^{129} \mathrm{I}$ release fraction, 0.112 , associated with the gap region of the fuel might be expected in the early test intervals. The remaining portion, 0.19 , of its cumulative released fraction should be associated with release from grain boundaries and grains as they are opened by oxidation of the fuel. Since the fission gas release for ATM-103 was $0.25 \%$, its gap release fraction would be 0.0025 . The remaining portion of its cumulative fraction, 0.10 , should also be associated with grainboundary and grain release. Gray ${ }^{1}$ noted that the matrix release rate for ATM-103 fuel was $0.04 \% / \mathrm{d}$ for fuel grains and $0.002 \% / \mathrm{d}$ for fuel fragments. If fuel grains are the reaction site in our tests and a reaction rate of $0.02 \% / \mathrm{d}$ (the average of the two rates) was maintained during the first 1.6 years of reaction, then we would expect a cumulative release fraction from the matrix of 0.13 . This value is comparable to the non-gap cumulative fractions observed for ATM106 and ATM-103, 0.19 and 0.10 , respectively.

At the 1.6-year test interval, the ${ }^{99} \mathrm{Tc}$ averaged fractional release rate, $1 \times 10^{-4} / \mathrm{d}$, for the ATM-106 fuel was orders of magnitude larger than the ${ }^{137} \mathrm{Cs}$ release rate, $2 \times 10^{-6} / \mathrm{d}$. For the ATM-103 fuel, the 1.6-year interval release rate was similar, $6 \times 10^{-4} / \mathrm{d}$ for ${ }^{99} \mathrm{Tc}$ and $2 \times 10^{-6} / \mathrm{d}$ for ${ }^{137} \mathrm{Cs}$. In flow-through tests ${ }^{1}$ at $25^{\circ} \mathrm{C}$, the matrix dissolution rate for ${ }^{99} \mathrm{Tc}$ was the same order of magnitude as ${ }^{238} \mathrm{U}$ 's. The calculated rate for matrix dissolution at $90^{\circ} \mathrm{C}$ for an activation energy of $30 \mathrm{~kJ} / \mathrm{mol}^{2}$ was $9 \times 10^{-5} / \mathrm{d}$, a rate which was comparable to our ${ }^{99} \mathrm{Tc}$ rates at $90^{\circ} \mathrm{C}$. These results suggest that

${ }^{99} \mathrm{Tc}$ release may indeed reflect matrix dissolution under the conditions of our tests. If the ${ }^{99} \mathrm{Tc}$ release behavior is maintained in future test intervals, then ${ }^{99} \mathrm{Tc}$ release may be used as an indication of the magnitude of matrix dissolution.

\section{CONCLUSIONS}

The release fractions for ${ }^{137} \mathrm{Cs},{ }^{90} \mathrm{Sr},{ }^{129} \mathrm{I}$, and ${ }^{99} \mathrm{Tc}$ were examined to determine if any of them reflected the rate of matrix dissolution under the unsaturated conditions that may be expected in the Yucca Mountain repository. Both ${ }^{137} \mathrm{Cs}$ and ${ }^{90} \mathrm{Sr}$ appear to be incorporated into alteration products, which reduced the amount of material released. The ${ }^{129} \mathrm{I}$ fractions, which were very large in the first two test intervals, decreased during later time intervals.

The cause of the major part of the decrease is exhaustion of the gap ${ }^{129} \mathrm{I}$ inventory. Large ${ }^{99} \mathrm{Tc}$ fractions, which were comparable to those reported by $\mathrm{Gray}^{1,2}$ for matrix dissolution, were found for ATM-103 throughout the 1.6 years of testing. At the 1.6-years interval a comparable ${ }^{99} \mathrm{Tc}$ release fraction was noted for the ATM-106 fuel. Thus, it appears that ${ }^{99} \mathrm{Tc}$ release may provide evidence for the magnitude of the spent fuel reaction under the unsaturated conditions used in the present tests.

\section{REFERENCES}

1. W. J. Gray, D. M. Strachan, and C. N. Wilson, "Gap and Grain Boundary Inventories of $\mathrm{Cs}, \mathrm{Tc}$, and $\mathrm{Sr}$ in Spent LWR Fuel," Mater. Res. Soc. Symp. Proc. 257, 353 (1992).

2. W. J. Gray, H. R. Leider, and S. A. Steward, "Parametric Study of LWR Spent Fuel Dissolution Kinetics," J. Nucl. Mater., 190, 46 (1992).

3. P. A. Finn, E. C. Buck, M. Gong, J. C. Hoh, J. W. Emery, L. D. Hafenrichter, and J. K. Bates, "Colloidal Products and Actinide Species in Leachate from Spent Nuclear Fuel," Radiochimica Acta, 66/67, 189 (1994).

4. P. A. Finn, J. C. Hoh, M. Gong, S. F. Wolf, S. A. Slater, and J. K. Bates, "The Release of Actinides, Cesium, Strontium, Technetium, and Iodine from Spent Fuel Under Unsaturated Conditions," submitted to Radiochimica Acta.

5. R. Wuertz and M. Ellinger, "Source Term for the Activity Release from a Repository for Spent LWR Fuel," Mater. Res. Soc. Symp. Proc. 50, 393 (1985). 
Table 1. Distribution of Radionuclides in Spent Fuel Pellets

\begin{tabular}{|c|c|c|c|c|}
\hline Location & ${ }^{137} \mathrm{Cs}$ & ${ }^{129} \mathrm{I}$ & ${ }^{99} \mathrm{Tc}$ & ${ }^{90} \mathrm{Sr}$ \\
\hline & \multicolumn{4}{|c|}{ Gray $^{\mathrm{a}}[1]$} \\
\hline Gap & $0.003-0.04$ & $\mathrm{NR}^{0}$ & $\leq 0.001$ & $\leq 0.001$ \\
\hline Grain-boundary & $0.005-0.01$ & NR & $\leq 0.001$ & $\leq 0.001$ \\
\hline Matrix & $\geq 0.96$ & NR & $>0.99$ & $>0.99$ \\
\hline & \multicolumn{4}{|c|}{ Wuertz and Ellinger $^{c}[5]$} \\
\hline & $\leq 0.05$ & $\leq 0.015$ & $\leq 0.015$ & $\overline{\mathrm{NR}}$ \\
\hline Grain-boundary & 0 & 0 & 0.485 & NR \\
\hline Matrix & 0.95 & 0.985 & 0.5 & NR \\
\hline
\end{tabular}

${ }^{2}$ For ${ }^{137} \mathrm{Cs}$ the gap and grain-boundary releases were reported as a function of the fission gas release. For

ATM-103, they were 0.003 and 0.005 ; for ATM-106, they were 0.03 and 0.01 .

${ }^{\mathrm{b}} \mathrm{NR}=$ Not reported.

'The fission gas release characteristics of the LWR fuels was not reported.

Table 2. Radionuclide Release in Drip Rate Tests

\begin{tabular}{|c|c|c|c|c|c|c|}
\hline & \multicolumn{3}{|c|}{ ATM-103 } & \multicolumn{3}{|c|}{ ATM-106 } \\
\hline & $\begin{array}{l}\text { Reaction } \\
\text { Time, yr }\end{array}$ & $\begin{array}{c}\text { Fraction }{ }^{\mathrm{a}} \\
\text { Release }\end{array}$ & $\begin{array}{c}\text { Release } \\
\text { Rate, } \\
\text { fraction } / \mathrm{d}\end{array}$ & $\begin{array}{l}\text { Reaction } \\
\text { Time, yr }\end{array}$ & $\begin{array}{c}\text { Fractional } \\
\text { Release }\end{array}$ & $\begin{array}{c}\text { Release } \\
\text { Rate, } \\
\text { fraction } / \mathrm{d}\end{array}$ \\
\hline \multirow[t]{4}{*}{${ }^{238} \mathrm{U}$} & 0.3 & $5 \mathrm{E}-5$ & $4 \mathrm{E}-7$ & 0.3 & $2 \mathrm{E}-5$ & $2 \mathrm{E}-7$ \\
\hline & 0.8 & $5 \mathrm{E}-6$ & $3 \mathrm{E}-8$ & 0.8 & $1 \mathrm{E}-4$ & $9 \mathrm{E}-7$ \\
\hline & 1.3 & $8 \mathrm{E}-6$ & $4 \mathrm{E}-8$ & 1.3 & $7 \mathrm{E}-6$ & $4 \mathrm{E}-8$ \\
\hline & 1.6 & $2 \mathrm{E}-5$ & $2 \mathrm{E}-7$ & 1.6 & $1 \mathrm{E}-6$ & $1 \mathrm{E}-8$ \\
\hline \multirow[t]{4}{*}{${ }^{137} \mathrm{Cs}$} & 0.3 & $7 \mathrm{E}-4$ & $1 \mathrm{E}-5$ & 0.3 & $4 \mathrm{E}-5$ & $1 \mathrm{E}-6$ \\
\hline & 0.8 & $2 \mathrm{E}-4$ & $1 \mathrm{E}-6$ & 0.8 & $2 \mathrm{E}-3$ & $1 \mathrm{E}-5$ \\
\hline & 1.3 & $9 \mathrm{E}-5$ & $4 \mathrm{E}-7$ & 1.3 & $1 \mathrm{E}-3$ & $5 E-6$ \\
\hline & 1.6 & $2 \mathrm{E}-4$ & $2 \mathrm{E}-6$ & 1.6 & $2 \mathrm{E}-4$ & $2 \mathrm{E}-6$ \\
\hline \multirow[t]{4}{*}{${ }^{90} \mathrm{Sr}$} & 0.3 & $2 \mathrm{E}-2$ & $2 \mathrm{E}-4$ & 0.3 & $4 \mathrm{E}-4$ & $3 \mathrm{E}-6$ \\
\hline & 0.8 & $4 \mathrm{E}-4$ & $2 \mathrm{E}-6$ & 0.8 & $3 \mathrm{E}-3$ & $2 \mathrm{E}-5$ \\
\hline & 1.3 & $9 \mathrm{E}-4$ & $4 \mathrm{E}-6$ & 1.3 & $9 \mathrm{E}-5$ & $4 \mathrm{E}-7$ \\
\hline & 1.6 & $3 \mathrm{E}-4$ & $3 \mathrm{E}-6$ & 1.6 & $2 \mathrm{E}-4$ & $2 \mathrm{E}-6$ \\
\hline \multirow[t]{4}{*}{${ }^{129} \mathrm{I}$} & 0.3 & $9 \mathrm{E}-2$ & $8 \mathrm{E}-4$ & 0.3 & 1E-1 & $9 \mathrm{E}-4$ \\
\hline & 0.8 & $5 \mathrm{E}-2$ & $3 \mathrm{E}-4$ & 0.8 & $2 \mathrm{E}-1$ & $1 \mathrm{E}-3$ \\
\hline & 1.3 & $2 \mathrm{E}-3$ & $1 \mathrm{E}-5$ & 1.3 & $1 \mathrm{E}-3$ & $6 \mathrm{E}-6$ \\
\hline & 1.6 & $2 \mathrm{E}-3$ & $2 \mathrm{E}-5$ & 1.6 & $4 \mathrm{E}-3$ & $4 \mathrm{E}-5$ \\
\hline \multirow{4}{*}{${ }^{99} \mathrm{Tc}$} & 0.3 & $4 \mathrm{E}-2$ & $3 E-4$ & 0.3 & $7 \mathrm{E}-5$ & $6 \mathrm{E}-7$ \\
\hline & 0.8 & $1 \mathrm{E}-2$ & $1 \mathrm{E}-4$ & 0.8 & $9 \mathrm{E}-4$ & $6 \mathrm{E}-6$ \\
\hline & 1.3 & $5 \mathrm{E}-2$ & $2 \mathrm{E}-4$ & 1.3 & $4 \mathrm{E}-4$ & $2 \mathrm{E}-6$ \\
\hline & 1.6 & $6 \mathrm{E}-2$ & $6 \mathrm{E}-4$ & 1.6 & $1 \mathrm{E}-2$ & 1E-4 \\
\hline
\end{tabular}

${ }^{\mathrm{a}}$ Interval fraction is the ratio of material released in an interval to that originally in the spent fuel sample.

${ }^{b}$ Rate is the ratio of the interval fraction divided by the length of the time interval.

DISCLAIMER

This report was prepared as an account of work sponsored by an agency of the United States Government. Neither the United States Government nor any agency thereof, nor any of their employees, makes any warranty, express or implied, or assumes any legal liability or responsibility for the accuracy, completeness, or usefulness of any information, apparatus, product, or process disclosed, or represents that its use would not infringe privately owned rights. Reference herein to any specific commercial product, process, or service by trade name, trademark, manufacturer, or otherwise does not necessarily constitute or imply its endorsement, recommendation, or favoring by the United States Government or any agency thereof. The views and opinions of authors expressed herein do not necessarily state or reflect those of the United States Government or any agency thereof. 